Did the global financial crisis impact firms' innovation performance? The role of internal and external knowledge capabilities in high and low tech industries

\title{
Ferdaous Zouaghi
}

Department of Business, Public University of Navarra,

Edificio Madroños, Campus Arrosadía, 31006, Pamplona, Spain.

ferdaous.zouaghi@unavarra.es

\section{Mercedes Sanchez Garcia}

Department of Business, Public University of Navarra,

Edificio Madroños, Campus Arrosadía, 31006, Pamplona, Spain.

mersan@unavarra.es

\section{Marian Garcia Martinez (Corresponding author)}

Kent Business School, University of Kent,

Canterbury, Kent CT2 7PE, United Kingdom

m.garcia@kent.ac.uk

This is an Accepted Manuscript of an article to be published in Technological Forecasting and Social Change. 
Did the global financial crisis impact firms' innovation performance? The role of internal and external knowledge capabilities in high and low tech industries

\begin{abstract}
This paper examines the role exerted by internal innovation efforts and external knowledge assets as dynamic capabilities to overcome adverse economic conditions. Additionally, we examine the differential impacts of the financial crisis in high and lowtech industries. Using panel data of manufacturing firms in Spain for the period 20062013, our results show that maintaining strong internal and external knowledge capabilities enables firms to mitigate the effects of the financial crisis. Findings emphasise the value of human capital, by enabling internal capabilities, as a coping mechanisms in low-tech sectors during the financial downturn. Similarly, open innovation allows firms to minimise the resources limitations and risk surrounding innovation, particularly during the financial crisis. This study provides valuable insights to managers aiming to develop strong internal knowledge bases to remain competitive under uncertain financial conditions.
\end{abstract}

\title{
Keywords
}

Financial crisis, innovation performance, internal capabilities, R\&D human capital, external knowledge resources. 


\section{Introduction}

The global financial crisis has made business opportunities less certain forcing companies to postpone long-term innovation investments (Archibugi et al., 2013; Cincera et al., 2012; Colombo et al., 2016; Filippetti and Archibugi, 2011; Paunov, 2012). Public and private R\&D investment in most OECD countries has declined since the start of the economic downturn in 2008 (OECD, 2012). Despite an overall fall in firms' innovation efforts, empirical research has demonstrated that firms have continued to deploy innovation strategies to remain competitive during the financial crisis (Colombo et al., 2016; Zouaghi and Sánchez, 2016). According to Hausman and Johnston (2014), the development of new innovations and technologies during the recession period has become crucial to gain competitive advantage.

The innovation literature notes that firms' innovative capacity depends greatly on external competitive pressures (Hansen et al., 2014; Kafouros, 2008). Competing in markets characterized by high levels of instability requires different resources and innovation strategies to those needed to succeed in stable markets (Lee and Makhija, 2009). Colombo et al. (2016) note that high-tech entrepreneurial ventures have responded to the economic crisis through investments in product innovation and expansion into international markets. In contrast, low-tech industries might face additional difficulties in managing R\&D projects during a crisis (Berchicci et al., 2013) as they require greater internal organisational capabilities to adapt to rapidly changing external environments. While the return on research efforts might be limited in lowtech manufacturing firms due to lower competitive pressures (Hansen and Winther, 2014), such investments, however, are important in order to benefit from innovation activities in the long term (Kafouros, 2008). Reflecting the cumulative nature of knowledge (Lane et al., 2006; Zahra and George, 2002), firms need to develop strong internal capabilities to support their strategic objectives and survive during economic downturn conditions.

Despite extensive research on the impact of the global financial crisis on firms' innovation performance (e.g. Archibugi and Filippetti, 2013; Berchicci et al., 2013; Cincera et al., 2012; Filippetti and Archibugi, 2011; Laperche et al., 2011; Paunov, 2012), findings remain inconclusive. Further, the role exerted by firms' internal and external knowledge resources during the economic downturn are still largely underresearched (Colombo et al., 2016). In this paper, we argue that internal innovation efforts and external knowledge assets as dynamic capabilities provide firms with sources of competitive advantage (Zahra and George, 2002) that might enable them to overcome adverse economic conditions. 
Additionally, we examine the differential impact of the financial crisis in high and lowtech industries. Our hypothesising suggests that the heterogeneity of technological intensity in manufacturing sectors creates distinct contexts for knowledge creation and sharing that influence firms' ability to adjust to external economic pressures and new market situations (Berchicci et al., 2013). High-tech industries are characterised by high levels of technological sophistication and extensive R\&D activities (Covin et al., 1990), and are thereby more likely to survive the economic recession and position themselves well for the recovery period (Adcock et al., 2014). Internal resources accumulated during the pre-crisis period act as a stimulus to enhance growth performance during the crisis (Colombo et al., 2016). Low-tech industries, in contrast, acquire externally developed mature and well-established technologies, modify these or apply them in a new context (Bender, 2008); hence they show a strong dependence on the external provision of equipment and knowledge (Heidenreich, 2009). Zouaghi and Sánchez (2016) find that supplier-dominated industries (i.e., agri-food sector) use cooperation agreements to cope with the economic crisis. Therefore, we argue that maintaining strong internal and external knowledge capabilities would enable firms to mitigate the effects of the financial crisis.

This study makes two important contributions to the innovation management literature. First, we investigate the indirect impact of the recent financial crisis on innovation novelty - incremental and radical innovation performance. Downs and Mohr (1976) challenged the idea of a single theory of innovation and argued that each form of innovation could be explained by different predictive variables. Second, the paper examines how internal capabilities and external knowledge assets influenced innovation performance during the financial crisis. Past research has shown the direct effect of innovation investments on firms' innovation performance (Shefer and Frenkel, 2005; Zahra and George, 2002); however, there is limited understanding of their relative influence over the business cycle during pre-crisis and crisis periods (Cerrato et al., 2016). This study draws on the concept of dynamic capabilities, defined as "the ability to integrate, build and reconfigure internal and external competencies to address rapidly changing environments" (Teece et al., 1997; p 519). These capabilities encompass activities by which managers continuously configure assets into viable resource combinations (Fainshmidt et al., 2017), which makes them suitable to study performance differentials across manufacturing sectors during the financial crisis.

The paper proceeds as follows. Next, we provide an overview of the relevant literature and present the research hypothesis. We then outline our sample, measures and analytical techniques. The research results are reported, followed by a discussion of the theoretical and managerial implications of our findings. We conclude with a discussion of the study's limitations and suggested directions for future research. 


\section{Theoretical framework and hypotheses}

\subsection{Internal capabilities and firm innovation performance}

$R \& D$ intensity

The tacit nature of technological knowledge and the risks associated with the loss of technological competitiveness require internal investments in knowledge generation activities (Spithoven and Teirlinck, 2015). Extant research suggests that internal investments in R\&D improve firms' learning capabilities, often referred to as absorptive capacity (Cohen and Levinthal, 1990; Zahra and George, 2002), and constitute an important input to the development of intangible capital (Garcia Martinez et al., 2017; Gu et al., 2016). Prior studies suggest R\&D expenditure as a key factor determining a firm's capacity to innovate (Shefer and Frenkel, 2005; Van Beers and Zand, 2014). Segarra-Blasco and Arauzo-Carod (2008) argue that firms operating in markets characterised by strong competition, fast technological change with short product life cycles, and strong market turbulence are forced to continuously introduce new technological developments and innovations to remain competitive.

R\&D investments are also important in low-tech industries (Hansen and Winther, 2014; Hervas-Oliver et al., 2011; Hirsch-Kreinsen, 2008). Kafouros (2008) argues that the payoffs from investments in R\&D are indeed higher in low-tech firms due to lower competitive pressures, which enable firms to benefit over the long "useful-life" of lowtech products. Hervas-Oliver et al. (2011) find that low-tech firms that conduct internal R\&D activities enhance their absorptive capacity and product innovativeness. Van Beers and Zand (2014) point out that new product development is significantly influenced by internal R\&D investment in manufacturing firms and its continuity essential for higher innovation performance in low-tech industries. We therefore hypothesise that R\&D intensity increases the firm's knowledge base and is positively associated to firm innovation performance.

H1. R\&D intensity is positively associated to innovation performance.

\section{$R \& D$ human capital}

Human capital theory affirms that individual skills, knowledge and capabilities are valuable resources and an important source of economic productivity, and that these skills can be built through education and experience (Becker, 1964). R\&D human capital is responsible for transforming the idiosyncratic tacit and explicit knowledge, including learning abilities, experience, and abilities necessary to perform firms' activities (D'Este et al., 2012; Delgado-Verde et al., 2016). A highly skilled workforce 
can assimilate and integrate external knowledge into internal innovation processes (Huang et al., 2015; Teirlinck and Spithoven, 2013). In particular, highly task specific (skills) human capital is required to integrate external knowledge with a high degree of tacitness associated with highly sophisticated, complex technological processes (Gibbons and Waldman, 2004).

Human capital is central for manufacturing competiveness and product innovativeness. Garcia Martinez et al. (2017) argue that highly skilled R\&D staff is a valuable strategy for high and low-tech manufacturing industries to enhance innovation performance as it increases the stock of knowledge of an organisation. Hansen and Winther (2014) show that highly skilled employees are crucial in low-tech manufacturing firms to increase sales and innovativeness. Similarly, Hervas-Oliver et al. (2011) highlight that qualified human resources drive innovation in low-tech manufacturing industries. Thus, we argue that R\&D human capital matters for the determination of a firm's absorptive capacity and leads to superior innovation performance.

H2. R\&D human capital is positively associated to innovation performance.

\subsection{External knowledge sources and firm innovation performance}

Today's fast paced business environment and shortened product life cycles require firms to develop external links and external collaboration relationships to boost their innovative performance and meet new business challenges (Garcia Martinez et al., 2017). Inter-organisational alliances are increasingly recognised in the innovation management literature as 'access relationships' that enable partners to acquire nonredundant knowledge and capabilities residing outside their organisational and technological boundaries (Cui and O'Connor, 2012; Chesbrough, 2012; De Man and Duysters, 2005; Vasudeva and Anand, 2011). Resource-based scholars argue that strategic alliances facilitate access to diverse markets and technological knowledge (Lin, 2014; Zhou and Li, 2012) and boost innovation by enhancing combinatory search (Jiang et al., 2010; Lahiri and Narayanan, 2013). These advantages are hypothesised to be particularly relevant for breakthrough innovation and novel technologies (Datta and Jessup, 2013; Garcia Martinez, 2013) or following technological shocks that create demand for new resources (Asgari et al., 2017).

Such open strategies depends on contributions from across a network of partners ranging from suppliers of raw materials, equipment, research institutes to consumers and customers that create value for the end consumer (West and Lakhani 2008). Cooperation with suppliers is found to enhance efficiency and complement the technological-base of the firm (Belderbos et al., 2004; Un et al., 2010). Collaboration 
with universities and research institutes, on the other hand, can provide access to tailor made, cutting edge technologies (Tsai and Hsieh, 2009); however, it may require firms to collaborate with other actors in order to implement the technology (BergJensen et al., 2007). Horizontal alliances with partners at the same level of the value chain provide access to knowledge in design, prototyping, testing, development and new product introductions (George et al. 2001). Horizontal alliances are more likely to be strategically motivated to improve long-term product technology development whereas vertical alliances tend to be more concerned with cost reduction (Kotabe, 1990). Collaboration with competitors enables firms speedy market penetration (van Beers and Zand 2014) and access to technological abilities that can be difficult, timeconsuming, and costly to develop alone within their boundaries (Chen et al., 2011).

Building upon open innovation research, we consider the two dimensions of openness: (i) collaboration breadth and (ii) collaboration depth (Laursen and Salter, 2006). Collaboration breadth, defined as the number of external sources of knowledge and technology that firms rely upon in their innovative activities, aims to capture ecosystem diversity, ranging from narrow to broad collaboration as the number of external partners increases. The intensity of collaboration is capture by collaboration depth, ranging from surface to deep collaboration as collaborative interactions intensify.

Research has demonstrated the value of external linkages to augment in-house R\&D efforts. Laursen and Salter (2006) suggest that broader and deeper collaboration can provide firms with new ideas and resources for greater innovation performance. Similarly, Nieto and Santamaría (2007) and Chiang and Hung (2010) highlight that maintaining deep contacts with a large number of external knowledge sources may provide firms with new sources of ideas necessary to improve innovation performance. Furthermore, the breadth and depth of external knowledge search expose firms to multiple ideas broadening their knowledge base and their ability to assimilate and acquire new knowledge (Ferreras-Méndez et al., 2015). George et al. (2001) report that high-tech firms enter multiple alliance agreements to overcome uncertainty and optimise risks of organisational failure, and to access multiple knowledge and skills bases across the various phases of their value chain (George et al., 2001). A heterogeneous pool of knowledge and capabilities is expected to support high-tech firms' orientation towards the development of advanced technological and scientific know-how (Satta et al., 2016) and to remain competitive in their rapidly changing business environments (Garcia Martinez et al., 2017).

In the other hand, suppliers and consumers are important sources of innovation in low-tech firms to support their search strategies (Hansen and Winther, 2014; HervasOliver et al., 2011). These external knowledge sources allow low-tech firms to access 
varied knowledge that would be difficult to obtain elsewhere, and to better understand new markets and demand trends (Hansen and Winther, 2014; HirschKreinsen, 2008). Building on these arguments, we hypothesize that firms that have widely and deeply opened their search strategies tend to have higher innovation performance.

H3a. Collaboration breadth is positively associated to innovation performance.

H3b. Collaboration depth is positively associated to innovation performance.

\subsection{Moderating effect of the economic crisis on the relationship between $R \& D$ intensity} and innovation performance

The economic crisis is often associated with high levels of environmental uncertainty and significant downward shifts in demand levels (Cerrato et al., 2016). Under such economic conditions, it can be argued that investments in R\&D activities become increasingly risky for firms due to the inherent uncertainties in the commercialisation of new products and services and the fact that they could fail to bring sufficiently high payoffs to recoup production costs (Cruz-Castro and Sanz-Menéndez, 2016; Fernandes and Paunov, 2015).

Studies report that the financial crisis has forced many firms to postpone ongoing R\&D and innovation projects (Cincera et al., 2012; Filippetti and Archibugi, 2011; Paunov, 2012). Archibugi et al. (2013), in their analysis of three waves of the UK Community Innovation Survey (CIS), found that the lack of internal financial resources has hampered innovation during the crisis. A recent contribution by Cruz-Castro and SanzMenéndez (2016) shows that the Spanish public research sector is poorly equipped to resist the crisis, with public R\&D budgets decreasing in times of recession. Similarly, Milić (2013) suggests that investments in innovations and future growth are at risk during an economic crisis, when most organizations cut their R\&D budgets. Comin and Gertler (2006) provide evidence to support the pro-cyclical argument that R\&D investment and the global crisis have negatively reduced aggregate private investment in innovation.

Despite the fact that the financial crisis was global and investments in innovation sharply declined in most countries, the economic crisis has not affected every economic sector in the same way (OECD, 2012). In this study, we hypothesise that high and low-tech manufacturing sectors experienced different levels of competitive pressures resulting from the recession and have responded differently to the economic crisis. Firms in high-tech sectors might be able to continue developing customers in still-growing markets during a downturn period (Leadbeater and Meadway, 2008). For 
example, Bathelt et al. (2013) examined the regional resilience of manufacturing firms (i.e., automobile sector) during the economic crisis and found that these industries were better prepared to deal with the effects of the crisis due to ongoing adjustments and improvements of their value chains and the potential for novel product development. Supporting this view, the empirical literature has extensively argued that $R \& D$ is a major source of competitive advantage in high-tech industries engaged in rapid knowledge generation in response to rapidly changing dynamics of competitive forces and new technologies (Gu et al., 2016; Lin et al., 2006). Industry R\&D levels positively affect innovativeness (Van Beers and Zand, 2014); high-tech sectors take advantage of innovation opportunities compared to traditional industries (Almeida and Fernandes, 2008). Berchicci et al., (2013) showed that firms in low-tech industries are less likely to engage in innovation activities during economic downturns. Therefore, we argue that the economic crisis negatively moderates the relationship between R\&D intensity and firm innovation performance, with the impact expected to be higher in low-tech industries compared to high-tech sectors.

H4. The economic crisis negatively moderates the relationship between R\&D intensity and innovation performance. The positive association between R\&D intensity and innovation performance decreases in recessionary periods compared to expansion periods.

2.4. Moderating effect of the economic crisis on the relationship between R\&D human capital and innovation performance

The recent literature highlights the role of human capital during a time of crisis as a valuable resource to foster innovation and creativity. Filippetti and Archibugi (2011), for instance, showed the crucial role played by qualified human resources in mitigating the effects of the crisis, suggesting that the effects of the crisis in terms of human capital investments are not the same across European countries. The underlying argument is that in some countries the crisis has led to the migration of skilled workers, cuts in R\&D public spending and education.

In time of crisis, innovation requires sufficient capabilities through investment in human capital to find ways to increase production and reduce costs, as well as sufficient financial capital either to bring in outside talent or to introduce new equipment (Bathelt et al., 2013). Goedhuys and Sleuwaegen (2016) find that human capital is a key driver of firm growth and reduces firm failure. Hansen et al. (2014) highlight that qualified human resources are crucial in shaping innovation in low-tech manufacturing industries. Recent research by Dahl and Klepper (2015) suggest that more productive firms hire more talented employees, which gives rise to enduring firm capabilities and survival over-time. This finding are supported by Day (2016) who 
predicts that R\&D and human capital accumulation will continue to sustain economic growth under uncertain conditions. Thus, we argue that firms with high levels of human capital would be better positioned to survive adverse macroeconomic conditions.

Hypothesis 5. The economic crisis positively moderates the relationship between R\&D human capital and innovation performance. The positive association between R\&D human capital and innovation performance increases in recessionary periods compared to expansion periods.

\subsection{Moderating effect of the economic crisis on the relationship between external knowledge sources and firm innovation performance}

Another strategy that has become increasingly attractive for manufacturing firms during the crisis is the opening up of their innovation processes. Abramovsky et al. (2005) concluded that firms collaborate with external partners in order to overcome the perceived high risks involved in technological innovation and financial constraints. Cerrato et al. (2016) report a positive relationship between crossbreed acquisitions and short-term firm performance during a crisis. Similarly, Zouaghi and Sánchez (2016) highlight the benefits of open innovation in enhancing agri-food firms' innovative performance during crisis periods by enabling access to diverse markets and technological knowledge. Partnering with third-party partners with complementary assets leads to superior performance and helps firm to survive longer (Velu, 2015).

Collaborative approaches, given their double aim of pooling knowledge and sharing costs and risks of R\&D activities, should increase in periods of economic downturn (Laperche et al., 2011) in order to support firms' innovation capabilities. Extant open innovation literature argues that firms use external collaboration to boost innovative performance and meet new business challenges (Garcia Martinez et al., 2017). However, high and low-tech industries implement different collaborative R\&D strategies to enhance their competiveness. Hansen et al. (2014) suggest that low-tech firms focus their innovation strategies on enhancing their human capital stock and developing closer ties with suppliers. External collaboration can help low-tech firms to overcome the limitations of their own resources and know-how (Heidenreich, 2009). High-tech firms, in contrast, focus on the expansion of new distribution channels in international markets and assisting long-distance customers (Colombo et al., 2016). Based on the above arguments, we argue that:

H6. The economic crisis positively moderates the relationship between i) collaboration breath and ii) collaboration depth and innovation performance. The positive 
association between collaboration agreements and innovation performance increases in recessionary periods compared to expansion periods.

Our hypothesised model is depicted in Figure 1.

Figure1. Research model

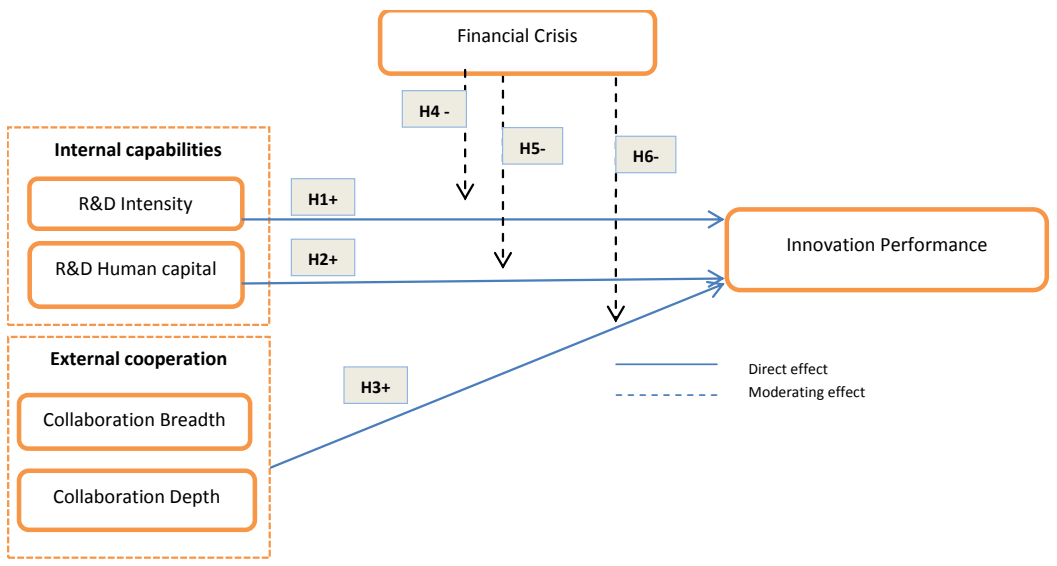

\section{Methodology}

\subsection{Data and sample}

The data for the quantitative analysis has been drawn from the Spanish Technological Innovation Panel (PITEC), which is a statistical instrument for studying the innovation activities of Spanish companies over time. The database ${ }^{1}$ is compiled by the Spanish National Statistics Institute (INE), in collaboration with the Spanish Science and Technology Foundation (FECYT) and the Foundation for Technological Innovation (COTEC). The PITEC dataset contains panel data for more than 13,000 firms since 2003.

The study was conducted using information on firms' innovation performance and different sources of external knowledge for the years 2006-2013. For the purposes of this research, the data set was restricted to manufacturing firms, based on the Spanish National Classification of Economic Activity (CNAE-2009), that have introduced radical or/and incremental innovations over the period 2006-2013. Our final sample contained 28,911 observations, 13,507 for high-tech sectors and 15,404 for low-tech sectors.

\footnotetext{
${ }^{1}$ The data base is available to researchers at the FECYT (Spanish Science and Technology Foundation) site: http://icono.fecyt.es/contenido.asp?dir=05\%29Publi/AA\%29panel.
} 


\subsection{Measures}

\section{Dependent variable}

Innovation performance is the dependent variable of the model measured as the percentage of the firm's total sales from innovations (Hitt et al., 1996). Consistent with CIS-based studies (e.g. Laursen and Salter, 2006, Sofka and Grimpe, 2010), we distinguish between incremental and radical innovation depending on their newness to the company or the market place, respectively. Radical innovation is measured as the percentage of the firm's total sales in year $t$ from innovations new to the market during the period between $t-2$ and $t$. Incremental innovation is defined as the percentage of the firm's total sales in year $t$ from innovations new to the firm during the period between $t-2$ and $t$.

\section{Independent variables}

$R \& D$ intensity has been defined as the ratio of expenditure by a firm on R\&D to the firm's total sales (Spithoven and Teirlinck, 2015). R\&D intensity is extensively used in innovation research as an innovation input measure (Mairesse and Mohnen, 2010).

$R \& D$ human capital was measured by the percentage of highly skilled R\&D workers (researchers and technicians) (Teixeira and Tavares-Lehmann, 2014). Highly qualified employees are regarded as a significant factor in innovation performance (Teirlinck, 2017).

Collaboration breadth is constructed as the combination of ten sources of knowledge for innovation: 1) suppliers, 2) customers, 3) competitors, 4) commercial research institutions and consultancy firms, 5) private laboratories and consultants, 6) universities and educational institutions, 7) public and non-profit research institutions, 8) trade fairs and exhibitions, 9) technical conferences, specialist journals and literature, and 10) professional associations. For each source, firms were asked to indicate whether the source was of high, medium, low, or no importance. We follow the procedure proposed by Laursen and Salter $(2006,2014)$ and Dong and Netten (2017) to code the ten external knowledge sources using a binary scale with $0=$ 'not used' and 1 = 'used'. Then, the ten sources are added up with the firm scoring 0 when no knowledge sources are used, while the firm gets a value of 10 when all knowledge sources are used. The set of items appears to have a high degree of internal consistency (Cronbach's alpha coefficient $=0.95$ ).

Collaboration depth: Following Laursen and Salter (2006) and Dong and Netten (2017), collaboration depth was defined as the intensity of collaboration with each partner 
type. In the survey, firms are asked to indicate in a four point Likert scale the intensity of collaboration with each external source (ranging from $0=$ "not used" to $4=$ "highly used"). Each source is coded as a binary variable in which 1 represents an external knowledge sources used to a high degree (4) and 0 when a given source is not used, or only to a low or medium degree ( 0 to 3 ). The ten dummies are added up so that each firm gets a score; 0 indicates no intense use of any external knowledge source, and 10 indicates intense usage of all 10 external knowledge sources (Cronbach's alpha coefficient $=0.72$ ).

\section{Moderation variables}

Financial crisis: we considered two time periods: pre-crisis (2006-2009) and crisis period (2010-2013) to better understand the long-term effects of the financial crisis on firm innovation performance. Our research interest is to examine if the impact of internal and external knowledge capabilities on innovation performance is significantly different between the time periods. We specify a year dummy to take account of the financial crisis as an indicator of downswings (Ugur et al., 2016) that takes the value 1 in years 2010-2013, and 0 otherwise (2006-2009).

\section{Control variables}

Firm size is measured as the natural logarithm of the number of employees, which influences firm innovation performance (Bayona et al., 2013). Productivity is defined as the natural logarithm for firm sales divided by the total number of employees in the firm (Antonioli et al., 2011). Finally, firms' innovation behaviour is closely linked to their industry affiliation (Audretsch, 1997; Malerba et al., 1997); hence we control for industry effects with dummy variables that indicate if the firm can be classified into high-tech and low-tech industries, according to the classification proposed by Van Beers and Zand (2014). Table A.1 in Appendix A describes the variables used in this study.

\subsection{Empirical Model}

We use random-effects panel Tobit models to test our hypotheses. The dependent variables (radical and incremental innovative performance) are percentage measures, and thereby conditioned on values between $0 \%$ and $100 \%$. The model is specified as follows: 


$$
\begin{aligned}
& Y_{i t}^{*}=X_{i t-1} \beta+\alpha_{i}+\varepsilon_{i t} \quad(\mathrm{i}=1 ; \ldots ; \mathrm{n} ; \mathrm{t}=1 ; \ldots ; \mathrm{T}) \\
& \text { While } \\
& \left\{\begin{array}{l}
\mathrm{y}_{\mathrm{it}}=\mathrm{y}^{*}{ }_{\text {it }} \text { if } \mathrm{y}^{*}{ }_{\mathrm{it}}>0 \\
\mathrm{y}_{\mathrm{it}}=0 \text { if } \mathrm{y}^{*}{ }_{\mathrm{it}} \leq 0
\end{array}\right.
\end{aligned}
$$

We make the usual random effects assumption that $\alpha_{i}$ and $\varepsilon_{i t}$ are independent and identically distributed of $x_{i 1}, \ldots, x_{i T}$, with zero means and variances $\sigma_{\alpha}^{2}$ and $\sigma_{\varepsilon}^{2}$, respectively (Mátyás and Sevestre, 2008). A log-transformation of both radical and incremental innovations variables is used to reduce the problem of non-normality of the residuals (Laursen and Salter, 2006).

In order to observe inter-sector differences, estimations are reported for two industry groups: high and low-tech industries. A standard one-tailed z-test is used to compare regression coefficients between the two groups (Van Beers and Zand, 2014):

$$
Z=\frac{\left|b_{1}-b_{2}\right|}{\sqrt{\sigma_{b_{1}}^{2}+\sigma_{b_{2}}^{2}}}
$$

Where $b_{1}$ and $b_{2}$ are the estimated coefficients associated with the two subsamples, and $\sigma_{\mathrm{b} 1}$ and $\sigma_{\mathrm{b} 2}$ are the standard errors.

To test the interaction effects ( $\mathrm{H} 4$ to $\mathrm{H} 6$ ), we follow the methodology proposed by Máñez et al. (2014) where a set of interaction terms between each explanatory variable and the financial crisis time variable is included in the Logit and Tobit models in order to capture the differential effects of the financial crisis for the two time periods (i.e., pre-crisis and crisis period). In addition to reporting the significance and the signs of the estimated coefficients for the interaction terms, we calculated the marginal effects and standard errors across a substantively meaningful range of the moderating variable while the other variables were constrained at their means to bring meaningful and informative marginal effects (Brambor et al., 2005). Previous studies have shown that interpreting the coefficients on constitutive terms as if they are unconditional marginal effects could be misleading, especially when the statistical model is nonlinear (Asongu and Nwachukwu, 2016).

\section{Results}

Table 1 reports the descriptive statistics, bivariate correlations, and the collinearity diagnostic for the variables used in the empirical study. Correlation values among all variables are generally low to moderate, suggesting there is a low risk of facing collinearity issues or redundancies with this set of variables. The highest correlation is 
0.54, far below the problematic level. The general rule of thumb is that correlation values should not exceed 0.75 (Tsui et al., 1995). This is confirmed by the analysis of Variance of Inflation (Vif) values. The maximum Vif value is 1.38 , well below the rule of thumb cut-off of 10 , which again indicates that there are no serious multicollinearity problems in the models (Neter et al., 1996). 
Table 1. Descriptive statistics and correlation matrix

\begin{tabular}{|c|c|c|c|c|c|c|c|c|c|c|c|}
\hline Variable & Mean & S.D. & 1 & 2 & 3 & 4 & 5 & 6 & 7 & 8 & 9 \\
\hline 1.Radical innovation & 9.21 & 21.71 & 1 & & & & & & & & \\
\hline 2.Incremental innovation & 14.36 & 27.44 & 0.01 & 1 & & & & & & & \\
\hline 3. R\&D intensity & 0.02 & 0.05 & $0.14^{*}$ & $0.07 *$ & 1 & & & & & & \\
\hline 4. R\&D human capital & 47.37 & 43.33 & $0.19 *$ & $0.18^{*}$ & $0.27^{*}$ & 1 & & & & & \\
\hline 5.Breadth search & 4.34 & 3.94 & $0.13 *$ & $0.13^{*}$ & $0.16^{*}$ & $0.42 *$ & 1 & & & & \\
\hline 6.Depth search & 0.83 & 1.36 & $0.09 *$ & $0.10^{*}$ & $0.13^{*}$ & $0.28^{*}$ & $0.54 *$ & 1 & & & \\
\hline 7. Firm size (Ln) & 4.14 & 1.37 & $0.02 *$ & $0.05^{*}$ & $-0.15^{*}$ & $0.19 *$ & $0.21 *$ & $0.10 *$ & 1 & & \\
\hline 8. Productivity & 12.05 & 0.78 & 0.01 & $0.04 *$ & $-0.18 *$ & $0.12^{*}$ & $0.13^{*}$ & $0.07^{*}$ & $0.03^{*}$ & 1 & \\
\hline 9. Financial crisis & 0.49 & 0.49 & -0.0 & $-0.05^{*}$ & $-0.14 *$ & $-0.03 *$ & $-0.09 *$ & $0.06 *$ & $-0.06^{*}$ & $-0.02 *$ & 1 \\
\hline VIF & & & 1.25 & 1.36 & 1.36 & 1.32 & 1.28 & 1.32 & 1.36 & 1.37 & 1.38 \\
\hline
\end{tabular}

$\mathrm{N}=28,911$

$* p<0.01$

S.D = Standard Deviation; Vif $=$ Variance Inflation Factor 
Tables 2 and 3 present the random-effects Tobit estimations regarding the probability of introducing radial and incremental innovations, respectively. For each subsample (i.e., high and low-tech sectors), we estimate six model specifications. Model 1 is the baseline model, which contains results of the main effects of control variables and the predictor variables. Models 2 to 5 separately report the results of the interaction effects between the independent variables and the financial crisis variable. Model 6 provides the results of the full model with main effects and interaction effects, including the control variables, predictor variables and the interaction terms. In addition to reporting the marginal effects of the regression for all interactions effects, we also provide interaction plots to explore the form of the interactions of firms' internal and external knowledge sources and the financial crisis. The chi-squares and the smaller values of the Akaike information criterion (AIC) and the Bayesian information criterion (BIC) in models compared with each previous model suggest that the relative goodness of fit in each model improved significantly on the previous one.

\section{Main effects}

$\mathrm{H} 1$ posits that R\&D intensity is positively associated to firm innovation performance. Models 1 (Tables 2 and 3 ) indicate that R\&D intensity is positively associated to radical and incremental innovation performance. Hence, $\mathrm{H} 1$ is accepted. A closer interpretation of the significant coefficients shows that R\&D intensity exerts the strongest effect on low-tech sectors. The difference between the two subsamples is statistically significant for both radical $(z=3.96, p<0.01)$ and incremental innovation performance $(z=1.45, p<0.1)$. This finding emphasises the importance of R\&D intensity in explaining innovation performance and differentiating across sectors (Van Beers and Zand, 2014).

$\mathrm{H} 2$ postulates that R\&D human capital is positively associated to innovation performance. Models 1 (Tables 2 and 3) show that the coefficient of R\&D human capital is positive and significant for both radical and incremental innovation $(p<0.00)$. Therefore, $\mathrm{H} 2$ is supported. However, the difference between both sectors is not statistically significant. H3 proposes that collaboration breadth and depth are positively associated to innovation performance. The results of the regression analysis depicted in Models 1 provide support to our hypothesising that collaboration dimensions are positively associated to both radical and incremental innovation $(p<0.05)$. Hence, H3 is supported. The difference between the two subsamples is not statistically significant.

Interestingly, Models 1 (Tables 2 and 3) show that the coefficient of financial crisis is negative and statistically significant for both innovation outputs. Results show that the crisis had a considerably larger impact on low-tech industries compared to high-tech 
industries. The difference between the two subsamples is statistically significant: radical innovation $(z=0.14, p<0.05)$ and incremental innovation $(z=0.36, p<0.01)$.

Model 1 shows that control variables are mostly statistically significant in the expected directions. Firm size has a positive and significant effect on the likelihood of introducing both radical and incremental innovation in both sectors. Firm productivity has a positive and significant effect on radical innovation performance in low-tech industries and incremental innovation performance in both industries. 
Table 2. Random-effects Tobit models for radical innovation performance

\begin{tabular}{|c|c|c|c|c|c|c|c|c|c|c|c|c|}
\hline \multirow[b]{3}{*}{ Direct effects } & \multicolumn{6}{|c|}{ High-Tech industries } & \multicolumn{6}{|c|}{ Low-Tech industries } \\
\hline & (1) & (2) & (3) & (4) & (5) & (6) & (1) & (2) & (3) & (4) & (5) & (6) \\
\hline & & & & & & & & & & & & \\
\hline H1. R\&D intensity $y_{t-1}$ & $\begin{array}{c}2.55^{* * *} \\
(0.60)\end{array}$ & $\begin{array}{c}1.95^{* * * *} \\
(0.68)\end{array}$ & $\begin{array}{c}2.52^{* * *} \\
(0.609\end{array}$ & $\begin{array}{c}2.47^{* * *} \\
(0.60)\end{array}$ & $\begin{array}{c}2.55^{* * *} \\
(0.60)\end{array}$ & $\begin{array}{c}1.98^{* * *} \\
(0.68)\end{array}$ & $\begin{array}{c}6.51^{* * *} \\
(0.96)\end{array}$ & $\begin{array}{c}5.51 * * * \\
(1.23)\end{array}$ & $\begin{array}{c}6.51^{* * * *} \\
(0.96)\end{array}$ & $\begin{array}{c}6.38 * * * \\
(0.96)\end{array}$ & $\begin{array}{c}6.44^{* * *} \\
(0.96)\end{array}$ & $\begin{array}{c}6.15^{* * *} \\
(1.23)\end{array}$ \\
\hline H2. R\&D human capital $\left.\right|_{t-1}$ & $\begin{array}{c}0.02^{* * *} \\
(0.00)\end{array}$ & $\begin{array}{c}0.02^{* * *} \\
(0.00)\end{array}$ & $\begin{array}{c}0.02^{* * *} \\
(0.00)\end{array}$ & $\begin{array}{c}0.02^{* * *} \\
(0.00)\end{array}$ & $\begin{array}{c}0.02^{* * *} \\
(0.00)\end{array}$ & $\begin{array}{c}0.02^{* * *} \\
(0.00)\end{array}$ & $\begin{array}{c}0.02 * * * \\
(0.00)\end{array}$ & $\begin{array}{c}0.02^{* * *} \\
(0.00)\end{array}$ & $\begin{array}{c}0.01^{* * *} \\
(0.00)\end{array}$ & $\begin{array}{c}0.02 * * * \\
(0.00)\end{array}$ & $\begin{array}{c}0.02^{* * *} \\
(0.00)\end{array}$ & $\begin{array}{c}0.02^{* * *} \\
(0.00)\end{array}$ \\
\hline H3a.Collaboration breadth $\mathrm{t}_{\mathrm{t}-1}$ & $\begin{array}{c}0.07^{* * *} \\
(0.01)\end{array}$ & $\begin{array}{c}0.07^{* * * *} \\
(0.01)\end{array}$ & $\begin{array}{c}0.06^{* * * *} \\
(0.01)\end{array}$ & $\begin{array}{c}0.04^{* * * *} \\
(0.01)\end{array}$ & $\begin{array}{c}0.07^{* * *} \\
(0.01)\end{array}$ & $\begin{array}{c}0.04^{* * * *} \\
(0.01)\end{array}$ & $\begin{array}{c}0.08 * * * \\
(0.01)\end{array}$ & $\begin{array}{c}0.080^{* * *} \\
(0.01)\end{array}$ & $\begin{array}{c}0.08 * * * \\
(0.01)\end{array}$ & $\begin{array}{l}0.03^{*} \\
(0.01)\end{array}$ & $\begin{array}{c}0.09 * * * \\
(0.01)\end{array}$ & $\begin{array}{l}0.04 * * \\
(0.02)\end{array}$ \\
\hline H3b. Collaboration depth ${ }_{\mathrm{t}-1}$ & $\begin{array}{l}0.06^{* *} \\
(0.03)\end{array}$ & $\begin{array}{c}0.06^{* * *} \\
(0.03)\end{array}$ & $\begin{array}{l}0.06^{* *} \\
(0.03)\end{array}$ & $\begin{array}{l}0.06^{* *} \\
(0.03)\end{array}$ & $\begin{array}{c}0.02 \\
(0.04)\end{array}$ & $\begin{array}{l}0.08^{*} \\
(0.04)\end{array}$ & $\begin{array}{l}0.07^{* *} \\
(0.03)\end{array}$ & $\begin{array}{l}0.07^{*} \\
(0.03)\end{array}$ & $\begin{array}{l}0.06^{*} \\
(0.03)\end{array}$ & $\begin{array}{c}0.07 * * \\
(0.03)\end{array}$ & $\begin{array}{l}-0.10^{*} \\
(0.05)\end{array}$ & $\begin{array}{c}0.04 \\
(0.05)\end{array}$ \\
\hline Controls & & & & & & & & & & & & \\
\hline Financial crisis & $\begin{array}{c}-0.76^{* * *} \\
(0.07)\end{array}$ & $\begin{array}{c}-0.78^{* * *} \\
(0.07)\end{array}$ & $\begin{array}{c}-0.79 * * * \\
(0.07)\end{array}$ & $\begin{array}{c}-0.88^{* * *} \\
(0.08)\end{array}$ & $\begin{array}{c}-0.77^{* * *} \\
(0.07)\end{array}$ & $\begin{array}{c}-0.89^{* * *} \\
(0.08)\end{array}$ & $\begin{array}{c}-0.90^{* * *} \\
(0.07)\end{array}$ & $\begin{array}{c}0.91 * * * \\
(0.07)\end{array}$ & $\begin{array}{c}-0.99 * * * \\
(0.08)\end{array}$ & $\begin{array}{c}-1.01^{* * *} \\
(0.08)\end{array}$ & $\begin{array}{c}-0.941^{* * *} \\
(0.07)\end{array}$ & $\begin{array}{c}-1.06^{* * *} \\
(0.08)\end{array}$ \\
\hline Firm size $e_{t-1}$ & $\begin{array}{c}0.23 * * * \\
(0.05)\end{array}$ & $\begin{array}{c}0.23 * * * \\
(0.05)\end{array}$ & $\begin{array}{c}0.23^{* * *} \\
(0.05)\end{array}$ & $\begin{array}{c}0.23 * * * \\
(0.05)\end{array}$ & $\begin{array}{c}0.23^{* * *} \\
(0.05)\end{array}$ & $\begin{array}{c}0.22^{* * *} \\
(0.05)\end{array}$ & $\begin{array}{c}0.52^{* * *} \\
(0.06)\end{array}$ & $\begin{array}{c}0.52^{* * *} \\
(0.06)\end{array}$ & $\begin{array}{c}0.52^{* * * *} \\
(0.06)\end{array}$ & $\begin{array}{c}0.50^{* * * *} \\
(0.06)\end{array}$ & $\begin{array}{c}0.51^{* * *} \\
(0.06)\end{array}$ & $\begin{array}{c}0.50^{* * *} \\
(0.06)\end{array}$ \\
\hline Productivity $_{\mathrm{t}-1}$ & $\begin{array}{c}0.11 \\
(0.07)\end{array}$ & $\begin{array}{c}0.12 \\
(0.07)\end{array}$ & $\begin{array}{c}0.11 \\
(0.07)\end{array}$ & $\begin{array}{c}0.11 \\
(0.07)\end{array}$ & $\begin{array}{c}0.11 \\
(0.07)\end{array}$ & $\begin{array}{c}0.11 \\
(0.07)\end{array}$ & $\begin{array}{c}0.26^{* * *} \\
(0.08)\end{array}$ & $\begin{array}{c}0.26^{* * *} \\
(0.09)\end{array}$ & $\begin{array}{c}0.26^{* * *} \\
(0.09)\end{array}$ & $\begin{array}{c}0.24^{* * *} \\
(0.09)\end{array}$ & $\begin{array}{c}0.25^{* * *} \\
(0.09)\end{array}$ & $\begin{array}{c}0.25^{* * *} \\
(0.08)\end{array}$ \\
\hline Interaction effects & & & & & & & & & & & & \\
\hline H4.R\&D intensity ${ }_{\mathrm{t}-1}{ }^{*}$ crisis & & $\begin{array}{l}1.58^{*} \\
(0.83)\end{array}$ & & & & $\begin{array}{l}1.29 * \\
(0.75)\end{array}$ & & $\begin{array}{c}1.70 \\
(1.37)\end{array}$ & & & & $\begin{array}{c}0.41 \\
(1.33)\end{array}$ \\
\hline H5. R\&D human capital ${ }_{\mathrm{t}-1}{ }^{*}$ crisis & & & $\begin{array}{c}0.02 \\
(0.02)\end{array}$ & & & $\begin{array}{l}-0.04 \\
(0.17)\end{array}$ & & & $\begin{array}{c}0.06^{* * * *} \\
(0.00)\end{array}$ & & & $\begin{array}{l}0.03^{* *} \\
(0.00)\end{array}$ \\
\hline $\begin{array}{l}\text { H6. Collaboration breadth }{ }_{\mathrm{t}} \\
{ }_{1}{ }^{*} \text { crisis }\end{array}$ & & & & $\begin{array}{c}0.07^{* * * *} \\
(0.02)\end{array}$ & & $\begin{array}{l}0.07^{* * *} \\
(0.02)\end{array}$ & & & & $\begin{array}{c}0.11^{* * *} \\
(0.02)\end{array}$ & & $\begin{array}{c}0.09 * * * \\
(0.02)\end{array}$ \\
\hline H6 Collaboration depth $\mathrm{t}_{\mathrm{t}-1}{ }^{*}$ crisis & & & & & $\begin{array}{c}0.06 \\
(0.04) \\
\end{array}$ & $\begin{array}{l}-0.03 \\
(0.05) \\
\end{array}$ & & & & & $\begin{array}{c}0.22 * * * \\
(0.05) \\
\end{array}$ & $\begin{array}{c}0.04 \\
(0.06)\end{array}$ \\
\hline Log-likelihood & -15085.3 & -15083.5 & -15084.3 & -15077.0 & -15084.3 & -15075.7 & 12444.2 & -12443.4 & -12436.1 & -12424.8 & -12435.8 & -12422.3 \\
\hline Wald $x 2$ & $595.8^{* * *}$ & $598.6^{* * *}$ & $595.8 * * *$ & $605.9 * * *$ & $596.8^{* * *}$ & $608.3^{* * *}$ & $777.1^{* * *}$ & $777.7^{* * *}$ & $781.5^{* * *}$ & $795.5^{* * *}$ & $786.8^{* * *}$ & $795.4^{* * *}$ \\
\hline Observations & 13,507 & 13,507 & 13,507 & 13,507 & 13,507 & 13,507 & 15,528 & 15,528 & 15,528 & 15,528 & 15,528 & 15,528 \\
\hline AIC & 30224.6 & 30222.9 & 30224.6 & 30210.04 & 30224.6 & 30213.4 & 24946.4 & 24946.7 & 24932.2 & 24909.6 & 24931.6 & 24910.6 \\
\hline $\mathrm{BIC}$ & 30427.4 & 30433.3 & 30434.9 & 30420.35 & 30434.9 & 30446.2 & 25166.1 & 25173.9 & 25159.5 & 25136.8 & 25158.8 & 25160.6 \\
\hline
\end{tabular}


Table 3. Random-effects Tobit models for incremental innovation performance

\begin{tabular}{|c|c|c|c|c|c|c|c|c|c|c|c|c|}
\hline \multirow[b]{3}{*}{ Direct effects } & \multicolumn{6}{|c|}{ High-Tech industries } & \multicolumn{6}{|c|}{ Low-Tech industries } \\
\hline & (1) & (2) & (3) & $(4)$ & (5) & (6) & (1) & (2) & (3) & (4) & (5) & (6) \\
\hline & & & & & & & & & & & & \\
\hline H1. R\&D intensity $\mathrm{y}_{\mathrm{t}-1}$ & $\begin{array}{c}1.98^{* * *} \\
(0.51)\end{array}$ & $\begin{array}{l}1.17 * * \\
(0.58)\end{array}$ & $\begin{array}{c}1.96^{* * *} \\
(0.51)\end{array}$ & $\begin{array}{c}1.91 * * * \\
(0.51)\end{array}$ & $\begin{array}{c}1.98^{* * *} \\
(0.51)\end{array}$ & $\begin{array}{c}1.29 * * \\
(0.58)\end{array}$ & $\begin{array}{c}3.43^{* * *} \\
(0.94)\end{array}$ & $\begin{array}{c}2.88^{* * * *} \\
(1.24)\end{array}$ & $\begin{array}{c}3.42^{* * *} \\
(0.94)\end{array}$ & $\begin{array}{c}3.26^{* * *} \\
(0.94)\end{array}$ & $\begin{array}{c}3.38^{* * *} \\
(0.95)\end{array}$ & $\begin{array}{c}3.99 * * * \\
(1.25)\end{array}$ \\
\hline H2. R\&D human capital $\left.\right|_{t-1}$ & $\begin{array}{c}0.02 * * * \\
(0.00)\end{array}$ & $\begin{array}{c}0.02^{* * *} \\
(0.00)\end{array}$ & $\begin{array}{c}0.01 * * * \\
(0.00)\end{array}$ & $\begin{array}{c}0.02 * * * \\
(0.00)\end{array}$ & $\begin{array}{c}0.02 * * * \\
(0.00)\end{array}$ & $\begin{array}{c}0.02^{* * *} \\
(0.00)\end{array}$ & $\begin{array}{c}0.02 * * * \\
(0.00)\end{array}$ & $\begin{array}{c}0.02 * * * \\
(0.00)\end{array}$ & $\begin{array}{c}0.01 * * * \\
(0.00)\end{array}$ & $\begin{array}{c}0.02 * * * \\
(0.00)\end{array}$ & $\begin{array}{c}0.02 * * * \\
(0.00)\end{array}$ & $\begin{array}{c}0.02 * * * \\
(0.00)\end{array}$ \\
\hline H3a.Collaboration breadth $\mathrm{t}_{\mathrm{t}-1}$ & $\begin{array}{c}0.07^{* * *} \\
(0.01)\end{array}$ & $\begin{array}{c}0.07^{* * *} \\
(0.00)\end{array}$ & $\begin{array}{c}0.07^{* * *} \\
(0.00)\end{array}$ & $\begin{array}{c}0.03^{* * *} \\
(0.01)\end{array}$ & $\begin{array}{c}0.07^{* * *} \\
(0.00)\end{array}$ & $\begin{array}{c}0.03^{* * *} \\
(0.01)\end{array}$ & $\begin{array}{c}0.10^{* * * *} \\
(0.01)\end{array}$ & $\begin{array}{c}0.10^{* * * *} \\
(0.01)\end{array}$ & $\begin{array}{c}0.09 * * * \\
(0.01)\end{array}$ & $\begin{array}{c}0.01 \\
(0.01)\end{array}$ & $\begin{array}{c}0.12^{* * *} \\
(0.01)\end{array}$ & $\begin{array}{c}0.03 \\
(0.03)\end{array}$ \\
\hline H3b. Collaboration depth $\mathrm{t}_{\mathrm{t}-1}$ & $\begin{array}{l}0.06^{* *} \\
(0.02)\end{array}$ & $\begin{array}{c}0.09 * * * \\
(0.02)\end{array}$ & $\begin{array}{c}0.09 * * * \\
(0.02)\end{array}$ & $\begin{array}{c}0.09 * * * \\
(0.02)\end{array}$ & $\begin{array}{c}0.02 \\
(0.03)\end{array}$ & $\begin{array}{l}0.08^{* *} \\
(0.03)\end{array}$ & $\begin{array}{c}0.09 * * * \\
(0.03)\end{array}$ & $\begin{array}{c}0.09 * * * \\
(0.03)\end{array}$ & $\begin{array}{c}0.09 * * * \\
(0.03)\end{array}$ & $\begin{array}{c}0.02 * * * \\
(0.00)\end{array}$ & $\begin{array}{c}-0.17^{* * *} \\
(0.05)\end{array}$ & $\begin{array}{c}0.04 * * * \\
(0.06)\end{array}$ \\
\hline Controls & & & & & & & & & & & & \\
\hline Financial crisis & $\begin{array}{c}-0.52^{* * *} \\
(0.05)\end{array}$ & $\begin{array}{c}-0.53^{* * *} \\
(0.06)\end{array}$ & $\begin{array}{c}-0.55 * * * \\
(0.06)\end{array}$ & $\begin{array}{c}-0.64 * * * \\
(0.06)\end{array}$ & $\begin{array}{c}-0.54 * * * \\
(0.06)\end{array}$ & $\begin{array}{c}-0.65^{* * *} \\
(0.06)\end{array}$ & $\begin{array}{c}-0.88^{* * *} \\
(0.06)\end{array}$ & $\begin{array}{c}-0.88^{* * *} \\
(0.07)\end{array}$ & $\begin{array}{c}-0.96 * * * \\
(0.07)\end{array}$ & $\begin{array}{c}-0.99 * * * \\
(0.07)\end{array}$ & $\begin{array}{c}-0.92^{* * *} \\
(0.07)\end{array}$ & $\begin{array}{c}-1.00^{* * *} \\
(0.07)\end{array}$ \\
\hline Firm size $\mathrm{t}_{\mathrm{t}-1}$ & $\begin{array}{c}0.22^{* * *} \\
(0.04)\end{array}$ & $\begin{array}{c}0.22^{* * *} \\
(0.04)\end{array}$ & $\begin{array}{c}0.22^{* * * *} \\
(0.03)\end{array}$ & $\begin{array}{c}0.22^{* * *} \\
(0.04)\end{array}$ & $\begin{array}{c}0.22^{* * *} \\
(0.04)\end{array}$ & $\begin{array}{c}0.21^{* * *} \\
(0.04)\end{array}$ & $\begin{array}{c}0.41^{* * * *} \\
(0.05)\end{array}$ & $\begin{array}{c}0.41 * * * \\
(0.05)\end{array}$ & $\begin{array}{c}0.41^{* * *} \\
(0.05)\end{array}$ & $\begin{array}{c}0.38^{* * *} \\
(0.05)\end{array}$ & $\begin{array}{c}0.40^{* * *} \\
(0.05)\end{array}$ & $\begin{array}{c}0.38^{* * *} \\
(0.05)\end{array}$ \\
\hline Productivity $_{\mathrm{t}-1}$ & $\begin{array}{l}0.15^{* *} \\
(0.06)\end{array}$ & $\begin{array}{c}0.16^{* * *} \\
(0.06)\end{array}$ & $\begin{array}{l}0.15^{* *} \\
(0.06)\end{array}$ & $\begin{array}{l}0.15^{* *} \\
(0.06)\end{array}$ & $\begin{array}{c}0.22 * * * \\
(0.04)\end{array}$ & $\begin{array}{c}0.15^{* * * *} \\
(0.06)\end{array}$ & $\begin{array}{c}0.22 * * * \\
(0.07)\end{array}$ & $\begin{array}{c}0.22 * * * \\
(0.08)\end{array}$ & $\begin{array}{c}0.22 * * * \\
(0.08)\end{array}$ & $\begin{array}{c}0.21 * * * \\
(0.08)\end{array}$ & $\begin{array}{c}0.22 * * * \\
(0.07)\end{array}$ & $\begin{array}{c}0.21 * * * \\
(0.05)\end{array}$ \\
\hline Interaction effects & & & & & & & & & & & & \\
\hline H4.R\&D intensity ${ }_{\mathrm{t}-1}{ }^{*}$ crisis & & $\begin{array}{c}2.11^{* * *} \\
(0.73)\end{array}$ & & & & $\begin{array}{c}1.66^{* *} \\
(0.75)\end{array}$ & & $\begin{array}{c}0.91 \\
(1.34)\end{array}$ & & & & $\begin{array}{c}1.20 \\
(1.36)\end{array}$ \\
\hline H5. R\&D human capital ${ }_{\mathrm{t}-1}{ }^{*}$ crisis & & & $\begin{array}{l}0.02 * * \\
(0.00)\end{array}$ & & & $\begin{array}{l}-0.01 \\
(0.01)\end{array}$ & & & $\begin{array}{c}0.06^{* * *} \\
(0.00)\end{array}$ & & & $\begin{array}{c}0.01 \\
(0.01)\end{array}$ \\
\hline $\begin{array}{l}\text { H6.Collaboration } \quad \text { breadth }_{\mathrm{t}-} \\
{ }_{1}{ }^{*} \text { crisis }\end{array}$ & & & & $\begin{array}{c}0.10^{* * *} \\
(0.01)\end{array}$ & & $\begin{array}{c}0.09 * * * \\
(0.01)\end{array}$ & & & & $\begin{array}{c}0.17^{* * *} \\
(0.02)\end{array}$ & & $\begin{array}{c}0.15^{* * *} \\
(0.02)\end{array}$ \\
\hline H6 Collaboration depth $\mathrm{t}_{\mathrm{t}-1}{ }^{*}$ crisis & & & & & $\begin{array}{c}0.12^{* * *} \\
(0.04)\end{array}$ & $\begin{array}{c}0.01 \\
(0.04)\end{array}$ & & & & & $\begin{array}{c}0.35 * * * \\
(0.05)\end{array}$ & $\begin{array}{c}0.09 \\
(0.06)\end{array}$ \\
\hline Log-likelihood & -18914.1 & -18909.9 & -18912.2 & -18892.8 & -18908.4 & -18890.3 & -16500.8 & -16500.6 & -16490.2 & -16446.7 & -16475.5 & -16444.6 \\
\hline Wald $\chi 2$ & $786.1^{* * *}$ & 793.1*** & $788.2^{* * *}$ & $819.2^{* * *}$ & $795.7^{* * *}$ & $823.9 * * *$ & $942.8^{* * *}$ & $942.8^{* * *}$ & $952.8^{* * *}$ & $1015.8^{* * *}$ & $980.1 * * *$ & $1017.5^{* * *}$ \\
\hline Observations & 13,507 & 13,507 & 13,507 & 13,507 & 13,507 & 13,507 & 15,528 & 15,528 & 15,528 & 15,528 & 15,528 & 15,528 \\
\hline AIC & 37882.3 & 37875.9 & 37880.4 & 37841.8 & 37872.7 & 37842.7 & 33059.7 & 33031.31 & 33040.5 & 32953.3 & 33011.2 & 32205.3 \\
\hline BIC & 38085.1 & 38086.2 & 38090.7 & 38052.1 & 38083.1 & 38075.5 & 33279.5 & 33288.6 & 33267.7 & 33180.6 & 33238.3 & 33205.3 \\
\hline
\end{tabular}

Notes: Standard error in parentheses. ${ }^{*}$ Significance at $1 \%{ }^{* *}$ significance at $5 \% ; * * *$ significance at $10 \%$. Sector dummy variables were included in the analysis but results are omitted here. 


\section{Interaction effects}

$\mathrm{H} 4$ predicts that the economic crisis negatively moderates the relationship between R\&D intensity and firm innovation performance. Contrary to our hypothesised relationship, the interaction term for $R \& D$ intensity $x$ financial crisis is significant but positive for high-tech radical $(b=1.58, p<0.1)$ and incremental innovation performance $(b=2.11, p<0.01)$ (Models 2 - Tables 2 and 3). For low-tech sectors, the interaction terms were not statistically significant. Hence, $\mathrm{H} 4$ is not supported.

This interpretation is further confirmed by Figures $2 a$ and $2 c$, which graphically represent the marginal effects of R\&D intensity on firm innovation performance for the two levels of the financial crisis variable (i.e., pre-crisis and crisis period). This type of graph, usually used to examine interaction effects (e.g., Barasa et al., 2017; Kingsley et al., 2017), allows us to correctly interpret the interaction effect in more detail (Corten et al., 2017). The marginal effects, illustrated by the solid lines, were calculated following Corten et al., (2017) procedure. The bars and dots surrounding the two lines indicate $95 \%$ confidence intervals. Figures $2 a$ and $2 c$ show that R\&D intensity has a significant and positive effect on high-tech innovative performance at both levels of the financial crisis variable. Additionally, this positive effect is found to be larger during the crisis period compared to the pre-crisis period for both innovation outputs. This result indicates that $R \& D$ intensity is particularly important for high-tech firms to remain competitive during the economic downturn.

To better understand the difference in the marginal effect of R\&D intensity on firm innovation performance between the two time periods, we plotted Figures $2 \mathrm{~b}$ and $2 \mathrm{~d}$. Figure $2 d$ confirms that the magnitude of this difference is statistically significant at the 95\% level for incremental innovation performance; for radical innovation performance the difference between the two time periods was not significant (Figure 2b). These findings suggest that the positive impact of R\&D intensity on high-tech innovation performance is higher during the crisis period and the marginal effects statistically significant for incremental innovation.

H5 posits that the positive relationship between R\&D human capital and firm innovation performance strengthens in times of crisis. The interaction term for R\&D human capital $x$ crisis is significant and positive for low-tech radical and incremental innovation performance $(B=0.06, p<0.01)$ and high-tech incremental innovation performance $(B=0.02, p<0.05)$. Hence, $\mathrm{H} 5$ is partially supported. Figures $3 c$ and $3 d$ show the difference in the marginal effects of R\&D human capital on innovation performance between the two time periods for low-tech industries. The magnitude of difference between the two periods differs from zero at the $95 \%$ level (Figure $3 \mathrm{~d}$ ). 
Findings suggest a positive moderating effect of the financial crisis on the relationship between R\&D human capital and low-tech innovation performance and this effect is more important during the crisis compared to the pre-crisis period. For high-tech industries, the importance of R\&D human capital increases during the crisis (Figure 3a), but the magnitude of difference between the two periods of time was non-significant (Figure $3 b$ ). These findings suggest that R\&D human capital exerts the same effect on high-tech innovation performance in pre-crisis and crisis periods.

Models 4 (Tables 2 and 3 ) show that the interaction terms for collaboration breadth $x$ financial crisis ( $\mathrm{H6a}$ ) are positive and significant for radical and incremental innovation performance. Hence, $\mathrm{H6a}$ is supported. Figure 4a shows that collaboration breadth has a significant and positive effect on high-tech innovation performance during both crisis time periods; this positive effect is greater during the crisis period, when the magnitude of the difference between both periods is significant at the $95 \%$ level (Figure 4b). For low-tech industries, the effect of collaboration breadth on innovation performance is not significant in the pre-crisis period but turns positive and significant in the crisis period (Figure 4c). These results suggest that collaboration breath is crucial to both high and low-tech industries during the crisis period, and comparatively more to low-tech firms.

Models 5 (Tables 2 and 3) show that the interaction terms for collaboration depth $\mathrm{x}$ financial crisis (H6b) are significant and positive for low-tech radical and incremental innovation performance and high-tech incremental innovation performance. Hence, $\mathrm{H} 6 \mathrm{~b}$ is partially supported. Figure $5 \mathrm{a}$ shows that the effect of collaboration depth on high-tech innovation performance is non-significant in the pre-crisis period; the lower 95\% confidence interval line crosses the zero line when the dummy period corresponds to the pre-crisis period. Therefore, when the period of time corresponds to the crisis period, both upper and lower 95\% confidence interval lines (dashes lines) are above the zero line. Figure $5 b$ confirms these results: the effect of collaboration depth is greater in the crisis period compared to the pre-crisis, in which the magnitude of difference was significant at the $95 \%$ level. For low-tech industries, Figures $5 c$ and $5 \mathrm{~d}$ show that the conditional impact of collaboration depth on firm performance is statistically significant and negative in the pre-crisis period, when both upper and lower 95\% confidence interval lines (dashes lines) are below the zero line, and this relationship turned positive and significant in the crisis period. These findings support our hypothesising that the effect of cooperation depth on firm innovation performance will be stronger during an economic crisis compared to the pre-crisis period, especially in low-tech sectors. 
Figure 2. Graphic presentations of the interaction effect between R\&D intensity and financial crisis for High-tech industries

(a)

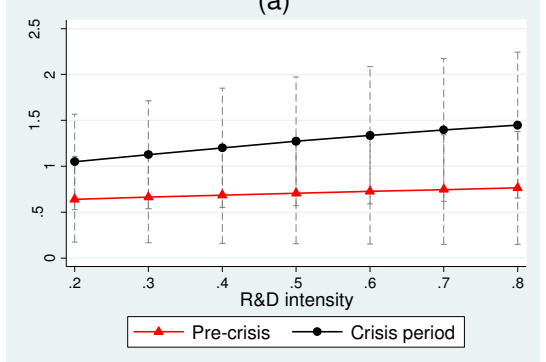

(c)

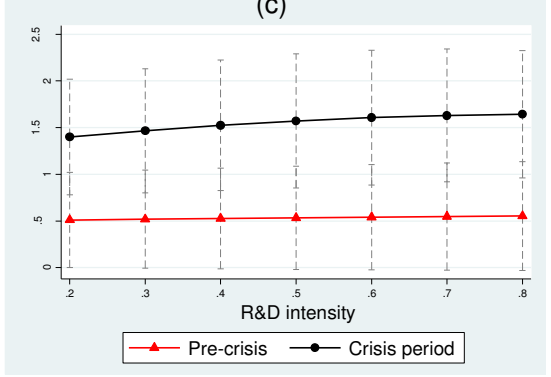

(b)

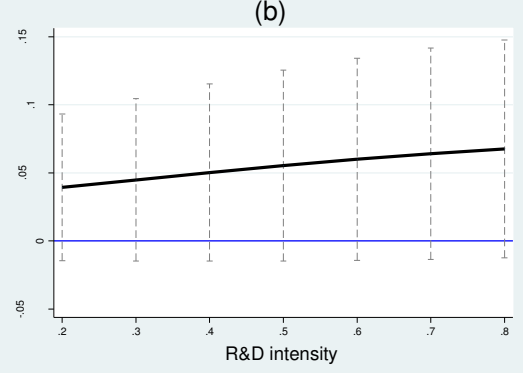

(d)

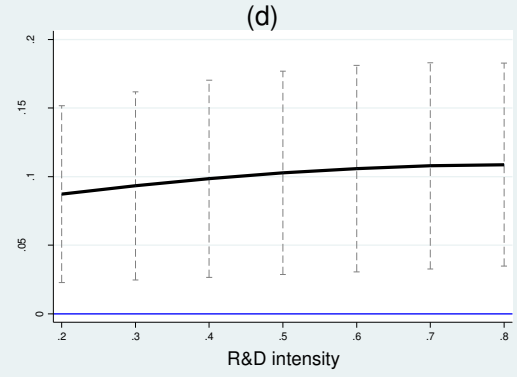

Figure 3. Graphic presentations of the interaction effect between R\&D human capital and financial crisis for High- (a-b) and Low-tech (c-d)

(a)

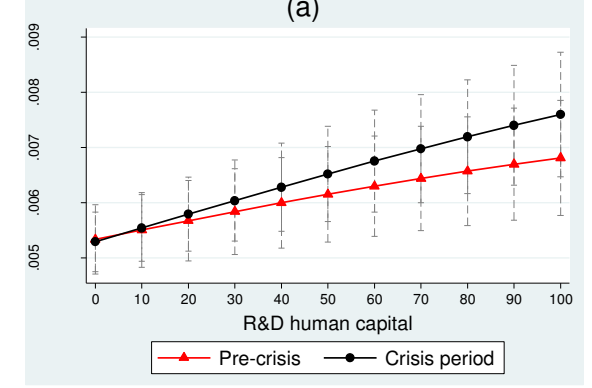

(c)
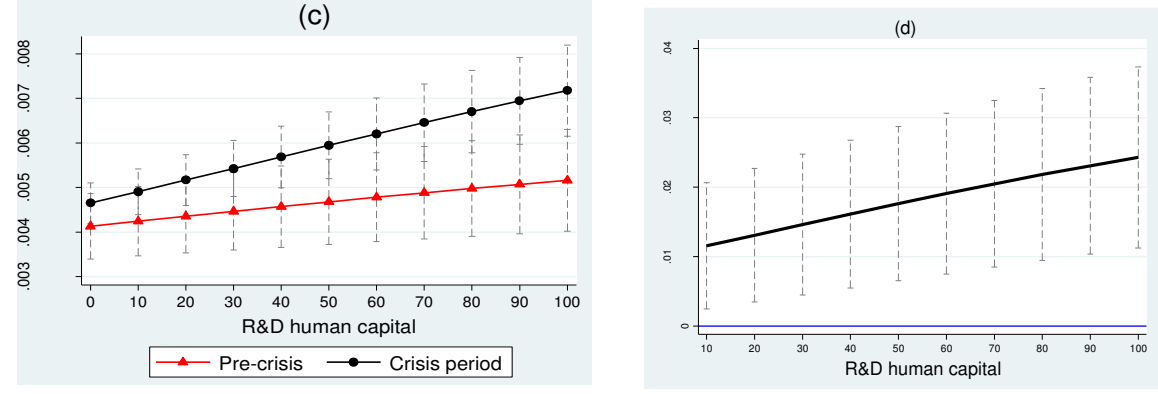
Figure 4. Graphic presentations of the interaction effect between cooperation breadth and financial crisis for High- (a-b) and Low-tech (c-d) firms

(a)

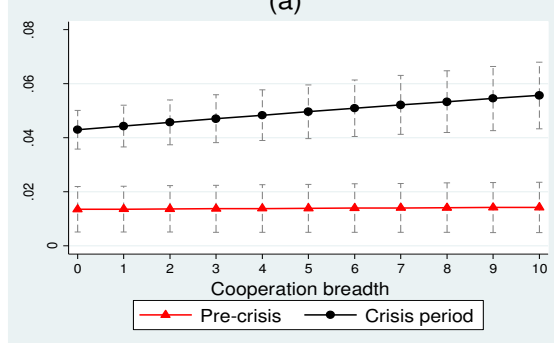

(c)

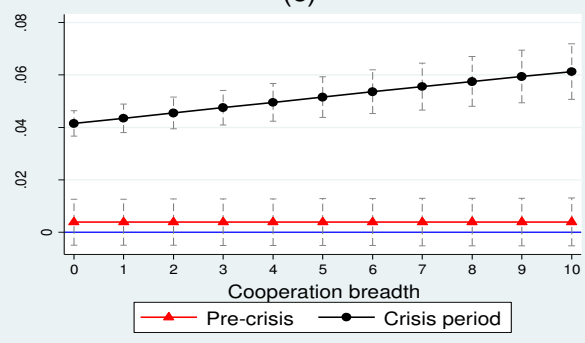

(b)

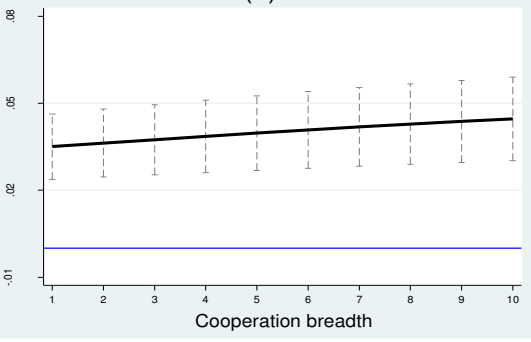

(d)

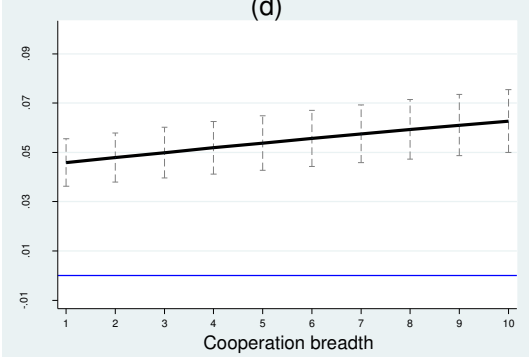

Figure 5. Graphic presentations of the interaction effect between collaboration depth and financial crisis for High- (a-b) and Low-tech (c-d)

(a)

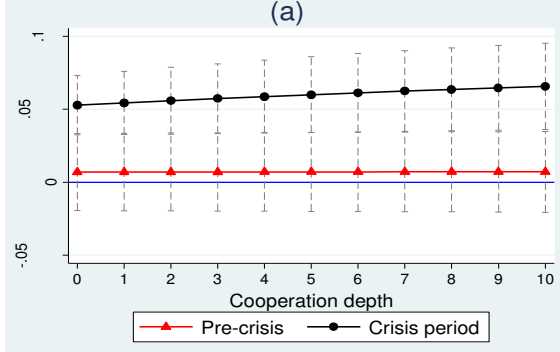

(c)

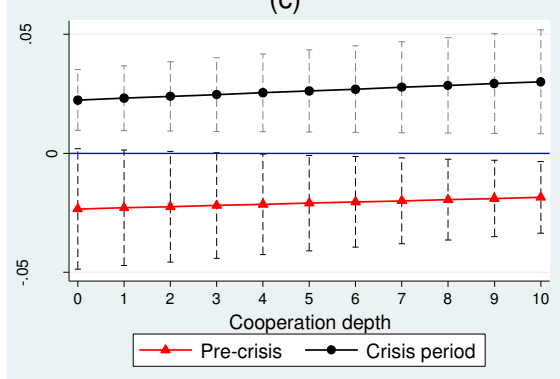

(b)

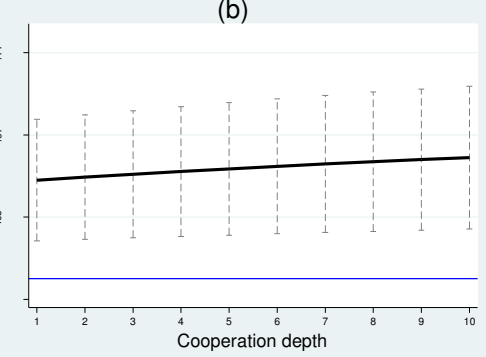

(d)

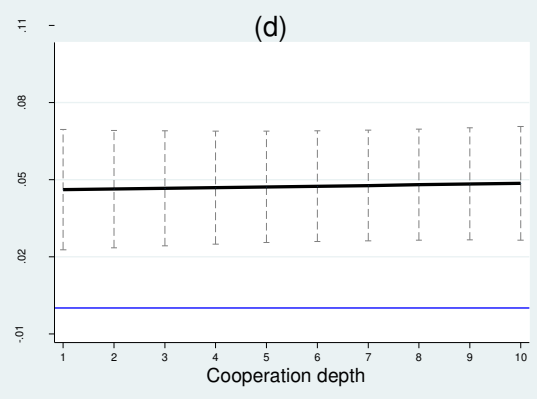




\section{Discussion and conclusion}

The aim of this paper was to investigate how the recent financial crisis has affected firm innovation performance and the role exerted by internal and external knowledge capabilities to enable firms overcome adverse economic conditions. In this paper, we complement emerging research efforts on the internal knowledge competencies shaping the capability of firms to remain competitive during the economic downturn (Nair et al., 2014). This paper shows the differential effects of internal innovation capabilities (i.e. R\&D intensity and R\&D human capital) and external knowledge sources on the firm innovative performance across different sub-sectors. Our study shows that strong internal knowledge bases yield strong absorptive capacity and lead to higher innovation performance. The results overemphasise the importance of firm internal R\&D efforts in explaining radical innovative performance for high-tech industries. The effect of R\&D intensity is particularly amplified during recession period, high-tech firms that have undertaken R\&D activities increase their ability to respond and survive the new changes of the environment.

Our findings suggest that human capital, by enabling internal capabilities, act as a coping mechanism to cushion the effect of the financial crisis on innovation performance. This effect is particularly important in low-tech industries, where human capital has a strong and positive association with innovation performance. These findings support previous studies highlighting the crucial role played by qualified human resources in reducing the effects of the financial crisis on innovation performance (e.g., Filippetti and Archibugi, 2011; Zouaghi and Sánchez, 2016). Lowtech industries generally possess limited internal capacity and resources for innovation (Hervas-Oliver et al., 2011). Hence, developing a knowledge base and dynamic capabilities (absorptive capacity) would enable low-tech sectors to mitigate the crisis effects and improve their innovative capacity (Hansen et al., 2014). Hansen and Winther (2011) emphasize the need for graduates with hybrid qualifications and high functional flexibility to allow low-tech firms to develop new profitable niches.

Our findings present strong evidence on the value of external knowledge assets to support innovation activities in times of crisis. Our empirical evidence confirms that low-tech industries that open up their innovation processes performed better during the crisis compared to the pre-crisis period. Research has shown that low-tech firms tend to seek external knowledge sources to offset their internal resource constraints and suppliers are the most important source of innovation and knowledge (HervasOliver et al., 2011). External R\&D collaboration can help low-tech industries develop innovation prospects and complement firms' proprietary knowledge in crisis time. 


\subsection{Contributions and managerial implications}

Several managerial implications follow from this discussion and should be of interest to managers. Explaining the role of internal and external knowledge capabilities as sources of firm innovation performance differentials among different sectors during the crisis helps managers to take advantage of more efficient bundles of these resources to achieve firm long-term viability. Managers in high-tech industries are advised to maintain and develop internal resources to adapt to their rapidly changing business environment. R\&D investments can help high-tech firms to improve their performance and to better adapt to the economic crisis. Our empirical research has shown the crucial role played by human capital in mitigating the effects of the crisis, particularly in low-tech sectors. Manufacturing managers in these sectors should keep their stock of skilled employees by monitoring the loss of innovation during the crisis period, which promotes higher levels of employment and job creation. Human capital, education and skills and training policy gives people within organizations the basis to introduce innovations and to ensure firm survival under conditions of hypercompetition. Managers in low-tech industries should be aware that although external resources are essential to achieve greater performance, they must be effectively integrated with internal capabilities into innovation processes. High level of internal capabilities is needed to ensure successful task coordination and assimilation of the external knowledge into the innovative process.

\subsection{Limitations and future research}

As is usually the case when it comes to research, this study faced some limitations and these could suggest lines of future research. First, our sample comes exclusively from the manufacturing industry. While this industry has often been used as a research context in the literature, future research could improve the generalizability of these findings by also including the service sector. Previous studies have shown distinct differences in innovation processes in manufacturing and service industries (Miozzo and Soete, 2001). It would be of great policy interest to make a comparative study to determine the difference in innovation behaviour in each sector during an economic crisis. Secondly, our study was confined to Spain; a future research path would be to carry out a comparative study of the innovative behaviour of Spanish firms during an economic crisis in relation to other countries. 


\section{ACKNOWLEDGEMENTS}

The authors gratefully acknowledge the funding received through the AGL2015-65897C03-1_R research project co-financed by FEDER, and they would also like to express their gratitude for the financial support received from the Caja Navarra Foundation and the Institute for Advanced Research in Business and Economics (INARBE, Public University of Navarre, Spain) for the acquisition of the Postdoctoral Fellowship.

\section{References}

Abramovsky, L., Kremp, E., Lopez, A., Schmidt, T., Simpson, H., 2005. Understanding Cooperative R\&D Activity: Evidence from Four European Countries (No. 05/23).

Adcock, C., Hua, X., Mazouz, K., Yin, S., 2014. Does the stock market reward innovation? European stock index reaction to negative news during the global financial crisis. Journal of International Money and Finance 49, 470-491.

Almeida, R., Fernandes, A.M., 2008. Openness and Technological Innovations in Developing Countries: Evidence from Firm-Level Surveys. Journal of Development Studies 44, 701-727.

Antonioli, D., Mazzanti, M., Pini, P., 2011. Innovation, industrial relations and employee outcomes: evidence from Italy. Journal of Economic Studies 38, 66-90.

Archibugi, D., Filippetti, A., 2013. Economic crisis and innovation: Is destruction prevailing over accumulation?. Research Policy 42, 303-314.

Archibugi, D., Filippetti, A., Frenz, M., 2013. The impact of the economic crisis on innovation: evidence from Europe. Technological Forecasting and Social Change $80,1247-1260$.

Asgari, N., Singh, K., Mitchell, W., 2017. Alliance portfolio reconfiguration following a technological discontinuity. Strategic Management Journal 38, 1062-1081.

Asongu, S.A., Nwachukwu, J.C., 2016. The Role of Governance in Mobile Phones for Inclusive Human Development in Sub-Saharan Africa. Technovation 55-56, 1-13.

Audretsch, D.B., 1997. Technological regimes, industrial demography and the evolution of industrial structures. Industrial and Corporate Change 6, 49-82.

Barasa, L., Knoben, J., Vermeulen, P., Kimuyu, P., Kinyanjui, B., 2017. Institutions, resources and innovation in East Africa: A firm level approach. Research Policy 46, 280-291.

Bathelt, H., Munro, A.K., Spigel, B., 2013. Challenges of transformation: innovation, re- 
bundling and traditional manufacturing in Canada's technology triangle. Regional Studies 47, 1111-1130.

Bayona, C., Cruz, C., Garcia, T., Sanchez, M., 2013. The effects of open innovation practicesof Spanish agri-food firms on the innovation per-formance, in: Martínez, G. (Ed.), Open Innovation in the Food and Beverage Industry. London: Woodhead Publishing Ltd., pp. 74-94.

Becker, W.C., 1964. Human Capital, The Univer. ed. Chicago.

Belderbos, R., Carree, M., Diederen, B., Lokshin, B., Veugelers, R., 2004. Heterogeneity in R\&D cooperation strategies. International Journal of Industrial Organization 22, 1237-1263.

Bender, G., 2008. How to Grasp Innovativeness of Organizations: outline of a conceptual tool., in: Hirsch-Kreinsen, H., Jacobson, D. (Eds.), Innovation in LowTech Firms and Industries. Cheltenham, Northampton: Edward Elgar, pp. 25-42.

Berchicci, L., Tucci, C.L., Zazzara, C., 2013. The influence of industry downturns on the propensity of product versus process innovation. Industrial and Corporate Change 23, 429-465.

Berg-Jensen, M., Johnson, B., Lorenz, E., Lundvall, B.A., 2007. Forms of knowledge and modes of innovation. Research Policy 36, 680-693.

Brambor, T., Clark, W.R., Golder, M., 2005. Understanding interaction models: Improving empirical analyses. Political analysis $14,63-82$.

Cerrato, D., Alessandri, T., Depperu, D., 2016. Economic crisis, acquisitions and firm performance. Long Range Planning 49, 171-185.

Cincera, M., Cozza, C., Tübke, A., Voigt, P., 2012. Doing R\&D or not (in a crisis), that is the question. European Planning Studies 20, 1525-1547.

Cohen, W.M., Levinthal, D.A., 1990. Absorptive capacity: A new perspective on learning and innovation. Administrative Sience Quarterly 35, 128-152.

Colombo, M.G., Piva, E., Quas, A., Rossi-Lamastra, C., 2016. How high-tech entrepreneurial ventures cope with the global crisis: changes in product innovation and internationalization strategies. Industry and Innovation 23, 647671.

Comin, D., Gertler, M., 2006. Medium-term business cycles. The American Economic Review 96, 523-551.

Corten, M., Steijvers, T., Lybaert, N., 2017. The effect of intrafamily agency conflicts on audit demand in private family firms: The moderating role of the board of 
directors. Journal of Family Business Strategy 8, 13-28.

Covin, J.G., Prescott, J.E., Slevin, D.P., 1990. The Effects of Technological Sophistication on Strategic Profiles, Structure and Firm Performance. The Journal of Management Studies 27, 485-510.

Cruz-Castro, L., Sanz-Menéndez, L., 2016. The effects of the economic crisis on public research: Spanish budgetary policies and research organizations. Technological Forecasting and Social Change. 133, 157-167.

Cui, A.S., O'Connor, G., 2012. Alliance Portfolio Resource Diversity and Firm Innovation. Journal of Marketing 76, 24-43.

Chen, J., Chen, Y., Vanhaverbeke, W., 2011. The influence of scope, depth, and orientation of external technology sources on the innovative performance of Chinese firms. Technovation 31, 362-373.

Chesbrough, H., 2012. Why companies should have open business models. MIT Sloan Management Review 48, 22-28.

Chiang, Y.H., Hung, K.P., 2010. Chiang, Y. H., \& Hung, K. P. (2010). Exploring open search strategies and perceived innovation performance from the perspective of inter-organizational knowledge flows. R\&D Management 40, 292-299.

D'Este, P., lammarino, S., Savona, M., von Tunzelmann, N., 2012. What hampers innovation? Revealed barriers versus deterring barriers. Research Policy 41, 482488.

Dahl, M.S., Klepper, S., 2015. Whom do new firms hire?. Industrial and Corporate Change 24, 819-836.

Datta, A., Jessup, L., 2013. Looking beyond the focal industry and existing technologies for radical innovations. Technovation 33, 355-367.

Day, C., 2016. Non-Scale Endogenous Growth with R\&D and Human Capital. Scottish Journal of Political Economy 63, 443-467.

De Man, A.-P., Duysters, G.G., 2005. Collaboration and innovation: a review of the effects of mergers, acquisitions and alliances on innovation. Technovation 25, 1377-1387.

Delgado-Verde, M., Martin-de Castro, G., Amores-Salvado, J., 2016. Intellectual capital and radical innovation: Exploring the quadratic effects in technology-based manufacturing firms. Technovation 54, 35-47.

Dong, J.Q., Netten, J., 2017. Information technology and external search in the open innovation age: New findings from Germany. Technological Forecasting and Social 
Change. In Press.

Downs Jr, G.W., Mohr, L.B., 1976. Conceptual issues in the study of innovation. Administrative Science Quarterly 21, 700-714.

Fainshmidt, S., Nair, A., Mallon, M.R., 2017. MNE performance during a crisis: An evolutionary perspective on the role of dynamic managerial capabilities and industry context. International Business Review (In press).

Fernandes, A., Paunov, C., 2015. The Risks of Innovation: Are Innovating Firms Less Likely to Die? Review of Economics and Statistics 97, 638-653.

Ferreras-Méndez, J.L., Newell, S., Fernández-Mesa, A., Alegre, J., 2015. Depth and breadth of external knowledge search and performance: The mediating role of absorptive capacity. Industrial Marketing Management 47, 86-97.

Filippetti, A., Archibugi, D., 2011. Innovation in times of crisis: National systems of innovation, structure, and demand. Research Policy 40, 179-192.

Garcia Martinez, M., 2013. Co-creation of value with consumers as an innovation strategy in the food and beverage industry: the case of Molson Coors' "talking can"., in: Garcia Martinez, M. (Ed.), Open Innovation in the Food and Beverage Industry. Cambridge: Woodhead Publishing., p. 139-153.

Garcia Martinez, M., Zouaghi, F., Sanchez Garcia, M., 2017. Capturing value from alliance portfolio diversity: The mediating role of R\&D human capital in high and low tech industries. Technovation 59, 55-67.

George, G., Zahra, S.A., Wheatley, K.K., Khan, R., 2001. The effects of alliance portfolio characteristics and absorptive capacity on performance: A study of biotechnology firms. The Journal of High Technology Management Research 12, 205-226.

Gibbons, R., Waldman, M., 2004. Task-specific human capital. The American Economic Review 94, 203-207.

Goedhuys, M., Sleuwaegen, L., 2016. High-growth versus declining firms: the differential impact of human capital and R\&D. Applied Economics Letters 23, 369372.

Gu, Q., Jiang, W., Wang, G.G., 2016. Effects of external and internal sources on innovation performance in Chinese high-tech SMEs: A resource-based perspective. Journal of Engineering and Technology Management 40, 76-86.

Hansen, T., Winther, L., 2014. Competitive low-tech manufacturing and challenges for regional policy in the European context-lessons from the Danish experience. Cambridge Journal of Regions, Economy and Society 7, 449-470. 
Hansen, T., Winther, L., 2011. Innovation, regional development and relations between high-and low-tech industries. European Urban and Regional Studies 18, 321-339.

Hansen, T., Winther, L., Hansen, R.F., 2014. Human Capital in Low-Tech Manufacturing: the Geography of the Knowledge Economy in Denmark. European Planning Studies 22, 1693-1710.

Hausman, A., Johnston, W.J., 2014. The role of innovation in driving the economy: Lessons from the global financial crisis. Journal of Business Research 67, 27202726.

Heidenreich, M., 2009. Innovation patterns and location of European low-and mediumtechnology industries. Research Policy 38, 483-494.

Hervas-Oliver, J.-L., Albors-Garrigós, J., Gil-Pechuan, I., 2011. Making sense of innovation by $R \& D$ and non-R\&D innovators in low technology contexts: $A$ forgotten lesson for policymakers. . Technovation 31, 427-446.

Hirsch-Kreinsen, H., 2008. “Low-Tech" Innovations. Industry and Innovation 15, 19-43.

Hitt, M.A., Hoskisson, R.E., Johnson, R.A., Moesel, D.D., 1996. The market for corporate control and firm innovation. Academy of Management Journal 39, 1084-1119.

Huang, K.-F., Lin, K.-H., Wu, L.-Y., Yu, P.-H., 2015. Absorptive capacity and autonomous R\&D climate roles in firm innovation. Journal of Business Research, 68, 87-94.

Jiang, R.J., Tao, Q.T., Santoro, M.D., 2010. Alliance portfolio diversity and firm performance. Strategic Management Journal 31, 113-1144.

Kafouros, M.I., 2008. Economic returns to industrial research. Journal of Business Research 61, 868-876.

Kingsley, A.F., Noordewier, T.G., Bergh, R.G. V., 2017. Overstating and understating interaction results in international business research. Journal of World Business 52, 286-295.

Kotabe, M., 1990. The relationship between offshore sourcing and innovativeness of U.S. of multinational firms. Journal of International Business Studies 21, 623-638.

Lahiri, N., Narayanan, S., 2013. Vertical integration, innovation, and alliance portfolio size: Implications for firm performance. Strategic Management Journal 34, 10421064.

Lane, P.J., Koka, B., Pathak, S., 2006. The reification of absorptive capacity: A critical review and rejuvenation of the construct. Academy of Management Review 31, 833-863. 
Laperche, B., Lefebvre, G., Langlet, D., 2011. Innovation strategies of industrial groups in the global crisis: Rationalization and new paths. Technological Forecasting and Social Change 78, 1319-1331.

Laursen, K., Salter, A., 2006. Open for innovation: the role of openness in explaining innovation performance among UK manufacturing firms. Strategic Management Journal 27, 131-150.

Leadbeater, C., Meadway, J., 2008. Attacking the Recession: How Innovation Can Fight the Downturn. Londo. NESTA.

Lee, S.H., Makhija, M., 2009. Flexibility in internationalization: is it valuable during an economic crisis? Strategic Management Journal 30, 537-555.

Lin, B.W., Lee, Y., Hung, S.C., 2006. R\&D intensity and commercialization orientation effects on financial performance. Journal of Business Research 59, 679-685.

Lin, J.Y., 2014. Effects on diversity of R\&D sources and human capital on industrial performance. Technological Forecasting and Social Change 85, 168-184.

Mairesse, J., Mohnen, P., 2010. Using innovations surveys for econometric analysis, in: Hall, B.H., Rosenber, N. (Eds.), Handbook of the Economics of Innovation. Amsterdam: Elsevier B.V., 1129-1155.

Malerba, F., Orsenigo, L., Peretto, P., 1997. Persistence of innovative activities, sectoral patterns of innovation and international technological specialisation. International Journal of Industrial Organisation 15, 801-826.

Máñez, J.A., Rochina-Barrachina, M. E. Sanchis-Llopis, J.A., Vicente, Ó., 2014. Financial constraints and R\&D and exporting strategies for Spanish manufacturing firms. Industrial and Corporate Change 23, 1563-1594.

Mátyás, L., Sevestre, P., 2008. The econometrics of panel data: fundamentals and recent developments in theory and practice, $3 \mathrm{rd}$. ed. Springer Science \& Business Media, Paris.

Milić, T., 2013. Innovation Management in Times of Economic Crisis. Management Journal for Theory and Practice Management 66, 81-88.

Miozzo, M., Soete, L., 2001. Internationalization of services: a technological perspective. Technological Forecasting and Social Change 67, 159-185.

Nair, A., Rustambekov, E., McShane, M., Fainshmidt, S., 2014. Enterprise risk management as a dynamic capability: A test of its effectiveness during a crisis. Managerial and Decision Economics 35, 555-566.

Neter, J., Kutner, M.H., Nachtsheim, C.J., Li, W., 1996. Applied Linear Statistical Models, 
Chicago:Trwin/McGraw-Hill.

Nieto, M.J., Santamaría, L., 2007. The importance of diverse collaborative networks for the novelty of product innovation. Technovation 27, 367-377.

OECD, 2012. Economic Policy Reforms Going for Growth. Paris, (Chapter 1).

Paunov, C., 2012. The global crisis and firms' investments in innovation. Research Policy 41, 24-35.

Satta, G., Parola, F., Penco, L., Esposito de Falco, S., 2016. Insights to technological alliances and financial resources as antecedents of high-tech firms' innovative performance. R\&D Management 46, 127-144.

Segarra-Blasco, A., Arauzo-Carod, J.M., 2008. Sources of innovation and industryuniversity interaction: Evidence from Spanish firms. Research Policy 37, 12831295.

Shefer, D., Frenkel, A., 2005. R\&D, firm size and innovation: an empirical analysis. Technovation 25, 25-32.

Sofka, W., Grimpe, C., 2010. Specialized search and innovation performance-evidence across Europe. R\&D Management 40, 310-323.

Spithoven, A., Teirlinck, P., 2015. Internal capabilities, network resources and appropriation mechanisms as determinants of R\&D outsourcing. Research Policy 44, 711-725.

Stanko, M.A., Henard, D.H., 2017. Toward a better understanding of crowdfunding, openness and the consequences for innovation. Research Policy 46, 784-798.

Teece, D.J., Pisano, G., Shuen, A., 1997. Dynamic capabilities and strategic management. Strategic Management Journal 18, 509-533.

Teirlinck, P., 2017. Configurations of strategic R\&D decisions and financial performance in small-sized and medium-sized firms. Journal of Business Research 74, 55-65.

Teirlinck, P., Spithoven, A., 2013. Research collaboration and R\&D outsourcing: Different R\&D personnel requirements in SMEs. Technovation 33, 142-153.

Teixeira, A.A.C., Tavares-Lehmann, A.T., 2014. Human capital intensity in technologybased firms located in Portugal: Does foreign ownership matter? Research Policy 43, 737-748.

Tsai, K.H., Hsieh, M.H., 2009. How different types of partners influence innovative product sales: Does technological capacity matter? Journal of Business Research 62, 1321-1328. doi:10.1016/j.jbusres.2009.01.003 
Tsui, A.S., Ashford, S.J., ST. Clair, L., Xin, K.R., 1995. Dealing with discrepant expectations: Response strategies and managerial effectiveness. Academy of Management Journal 38, 1515-1543.

Ugur, M., Trushin, E., Solomon, E., 2016. Inverted-U relationship between R\&D intensity and survival: evidence on scale and complementarity effects in UK data. Research Policy 45, 1474-1492.

Un, C.A., Cuervo-Cazurra, A., Asakawa, K., 2010. R\&D collaborations and product innovation. Journal of Product Innovation Management 27, 673-689.

Van Beers, C., Zand, F., 2014. R\&D cooperation, partner diversity, and innovation performance: An empirical analysis. Journal of Product Innovation Management 31, 292-312.

Vasudeva, G., Anand, J., 2011. Unpacking absorptive capacity: a study of knowledge utilisation from alliance portfolios. Academy of Management Journal 54, 611-623.

Velu, C., 2015. Business model innovation and third-party alliance on the survival of new firms. Technovation 35, 1-11.

Zahra, S.A., George, G., 2002. Absorptive capacity: A review, reconceptualization, and extension. Academy of Management Review 27, 185-203.

Zhou, Z.K., Li, B. caroline, 2012. How knowledge affects radical innovation: knowledge base, market knowledge acquistion, and internal knowledge sharing. Strategic Management Journal 33, 1090-1102.

Zouaghi, F., Sánchez, M., 2016. Has the global financial crisis had different effects on innovation performance in the agri-food sector by comparison to the rest of the economy? Trends in Food Science \& Technology 50, 230-242. 


\section{Appendix 1 - Table A.1. Variables Description}

\begin{tabular}{|l|l|}
\hline Variables & Definitions \\
\hline Dependent Variables & $\begin{array}{l}\text { Percentage of the firm's total sales in year } t \text { from innovations new to the market during the period between } \\
t-2 \text { and } t \text { (Ln) }\end{array}$ \\
\hline Radical innovation & $\begin{array}{l}\text { Percentage of the firm's total sales in year } t \text { from innovations new to the firm during the period between } t \text {-2 } \\
\text { and } t \text { (Ln) }\end{array}$ \\
\hline Incremental innovation & Ratio of expenditures by a firm on R\&D to the firm's sales \\
\hline Predictor Variables & Percentage of R\&D top skilled workers \\
\hline R\&D intensity & The number of distinct external knowledge sources (0-10) \\
\hline R\&D Human capital & The intensity of external knowledge search (0-10) \\
\hline Collaboration breadth & $\begin{array}{l}\text { Takes the value } 1 \text { if the observation corresponds to the period of crisis 2010-2013, 0 if the period is 2006- } \\
\text { 2009. }\end{array}$ \\
\hline Collaboration depth & \\
\hline Financial crisis & Number of employees (Ln) \\
\hline Control variables & Ratio of firm sales to the total firm employees (Ln) \\
\hline Firm size & Dummy variables indicating the sector where the firm operates \\
\hline Labour productivity & \\
\hline Industry dummy &
\end{tabular}

